${ }^{1}$ Amir , ${ }^{2}$ Murtalim, ${ }^{3}$ Muhammad chusnan Apriyanto, ${ }^{4}$ Muhamad Arif Rahman, ${ }^{5}$ Abel Alfarez

\title{
ANALISIS KERUSAKAN PADA RANTAI CONVEYOR
}

\author{
${ }^{1}$ Amir , ${ }^{2}$ Murtalim, ${ }^{3}$ Muhammad chusnan Apriyanto, ${ }^{4}$ Muhamad Arif Rahman, ${ }^{5}$ Abel Alfarez \\ 1,245 Universitas Buana Perjuangan Karawang \\ ${ }^{3}$ STT DR. Khez Muttaqien Purwakarta
}

Program Studi Teknik Mesin, Fakultas Teknik dan Ilmu Komputer

Program Studi Teknik Mesin STT DR. Khez Muttaqien Purwakarta

\author{
Amir 1 @ubpkarawang.ac.id \\ Murtalim²@ubpkarawang.ac.id \\ mchunanapriyanto3@gmail.com \\ tm19.arifrahman ${ }^{4} @$ mhs.ubpkarawang.ac.id \\ tm19.abelalfarez ${ }^{5} @$ mhs.ubpkarawang.ac.id
}

\begin{abstract}
Conveyor adalah suatu sistem mekanik yang mempunyai fungsi memindahkan barang dari suatu tempat ke tempat lain. Conveyor banyak dipakai di industri untuk transportasi barang yang jumlahnya sangat banyak dan berkelanjutan. Banyak jenis coveyor yang di gunakan di dunia industri di antara nya conveyor yang berbentuk rantai dengan disc teplon di selang satu setiap rangkaian rantai nya yang berjalan di dalam pipa. Untuk mengetahui penyebab kerusakan pada bagian rantai vonveyor tersebut, maka dilakukan beberapa pengujian seperti pengujian komposisi kimia, pengujian metalografi, pengujian kekerasan.

Berdasarkan pengamatan secara visual dan Pengujian komposisi kimia, Pengujian metalografi, pengujian kekerasan, dan analisa terhadap material rantai konveyor yang mengalami patah/putus, maka dapat disimpulkan sebagai berikut: Penyebab terjadinya patah/putusnya rantai konveyor yaitu dikarenakan material rantai konveyor tersebut memiliki konsentarsi tegangan dan kekerasan yang tinggi sehingga menjadi daerah yang rawan dan kritis terhadap fatique akibat tidak adanya PWHT (Post Welding Heat Treatment), tinginya nilai kekerasan pada daerah HAZ ini dapat mengakibatkan dearah tersebut semakin rentan terhadap putusnya material rantai konveyor tersebut.
\end{abstract}

Kata kunci: rantai, conveyor, komposisi kimia, metalografi, kekerasan,

\section{PENDAHULUAN}

Kebutuhan polyester di dunia dan nasional sangat di butuhkan dalam pembuatan dalam hasil tenun, maka Sebuah industry polumerisasi yang memproduksi polyester yang memproduksi 830 ton/hari dengan kualitas ISO 9001 : 2008, ISO 14001 : 2004 Dan OHSAS $18001: 2007$

Conveyor adalah suatu sistem mekanik yang mempunyai fungsi memindahkan barang dari suatu tempat ke tempat lain. Conveyor banyak dipakai di industri untuk transportasi barang yang jumlahnya sangat banyak dan berkelanjutan. Banyak jenis coveyor yang di gunakan di dunia industri di antara nya conveyor yang berbentuk rantai dengan disc teplon di selang satu setiap rangkaian rantai nya yang berjalan di dalam pipa.

Untuk memenuhi kebutuhan proses itu industry tersebut, di lengkapi dengan alat Conveyor PTA conveying yang salah satu komponen utamanya: Pipa konveyor, Rantai 
${ }^{1}$ Amir , ${ }^{2}$ Murtalim, ${ }^{3}$ Muhammad chusnan Apriyanto, ${ }^{4}$ Muhamad Arif Rahman, ${ }^{5}$ Abel Alfarez Vol 5 No 1 ISSN : 2541-6995

E ISSN : 2580-5517

konveyor dengan disc PE (di selang satu rantai nya), Motor penggerak, Gear Box, Sproket serta komponen Instument dan Elektrik lain nya yang menunjang bekerja nya Conveyor PTA ini.

\section{METODE PENELITIAN}

\section{Jenis Penelitian}

Pelaksanaan penelitian untuk mendapatkan penyelesaian dari masalah ini, dimulai persiapan material atau bahan uji yaitu bagian conveyor yang mengalami yang menjadi objek dalam penelitian sampai proses pengujian material tersebut. Untuk pengujian kerusakan pada bagian Conveyor yang mengalami kerusaka dilakukan di Laboratorium terpadu Teknik Mesin Universitas Buana Perjuangan dan PT Inteks Karawang.

\section{Waktu dan Tempat Penelitian}

Penelitian ini dilakukan selama bulan terhitung dari Februari sampai dengan 31 Agustus 2020. Penelitian dan pengujian ini dilaksanakan Laboratotium Terpadu Teknik Mesin Universitas Buana Perjuangan Karawang dan PT Inteks Karawang.

\section{Target/Subjek Penelitian}

\section{Populasi}

Untuk mendukung penelitian ini dilakukan metode pengumpulan data pendukung dengan cara inspeksi lapangan, pemeriksaan secara visual, pengambilan benda uji, pengujian material, dan data-data teknis yang lain seperti spesifikasi, desain, dan termasuk data kerusakan yang terjadi, data operasi, dan latar belakang terjadinya kerusakan rantai Conveyor. Proses pengumpulan data dalam penelitian ini adalah Melakukan pengamatan secara visual terhadap material rantai Conveyor yang mengalami kerusakan. Pemeriksaan sangat penting dilakukan sebelum melakukan pengujian laboratorium.

\section{Responden}

Responden merupakan bagian dari populasi yang mewakili populasi tersebut, yang diambil menurut prosedur tertentu (Suyito \& Sodik, 2015). Teknik sampling yang digunakan dalam penelitian ini adalah Cluster sampling (Area sampling). Teknik sampling daerah dipakai untuk menentukan sampel jika objek yang akan diteliti atau sumber data sangat luas, seperti misalnya penduduk dari suatu negara, provinsi atau dari suatu kabupaten (Suyito \& Sodik, 2015). Sampel dalam penelitian ini yaitu rantai konveyor yang mengalami kegagalan yaitu berupa putusnya rantai conveyor tersebut 
${ }^{1}$ Amir , ${ }^{2}$ Murtalim, ${ }^{3}$ Muhammad chusnan Apriyanto, ${ }^{4}$ Muhamad Arif Rahman, ${ }^{5}$ Abel Alfarez Vol 5 No 1

ISSN : 2541-6995

E ISSN : 2580-5517

\section{Prosedur Penelitian}

"Prosedure pengujian di awali dengan Menyiapkan bahan yang mau di uji dan sop pengujian yang di lakukan di Laboratotium Terpadu Teknik Mesin Universitas Buana Perjuangan Karawang dan PT Inteks Karawang.

Prosedur dalam penelitian ini merupakan tahapan-tahapan yang digunakan sebagai alat untuk mengumpulkan data dan menjawab permasalahan yang menjadi fokus penelitian. Tahapan-tahapan penelitian yang dilakukan dalam penelitian ini meliputi studi pendahuluan, rumusan masalah, penetapan tujuan, pengumpulan data, pengolahan data, analisis dan pembahasan, serta kesimpulan dan saran yang berkaitan dengan tema yang diangkat oleh peneliti yaitu analisa kerusakan pada rantai conveyor.

\section{Data, Instrumen, dan Teknik Pengumpulan Data}

Untuk mendukung penelitian ini dilakukan metode pengumpulan data pendukung dengan cara inspeksi lapangan, pemeriksaan secara visual, pengambilan benda uji, pengujian material, dan data-data teknis yang lain seperti spesifikasi, desain, dan termasuk data kerusakan yang terjadi, data operasi, dan latar belakang terjadinya kerusakan rantai Conveyor. Proses pengumpulan data dalam penelitian ini adalah Melakukan pengamatan secara visual terhadap material rantai Conveyor yang mengalami kerusakan. Pemeriksaan sangat penting dilakukan sebelum melakukan pengujian laboratorium.

\section{HASIL PENELITIAN DAN PEMBAHASAN}

\section{Hasil Penelitian}

\section{Hasil Pengujian Komposisi Kimia}

Analisa pengujian komposisi kimia pada material rantai conveyor dilakukan dengan menggunakan spectrometer, untuk mengetahui komposisi kimia yang terkandung pada material tersebut, sehingga hasil pengujian ini apakah komposisi material sudah sesuai dengan spesifikasi yang ditentukan untuk desain rantai conveyor. Hasil pengujian komposisi kimia dapat dilihat pada tabel .4.1.

\begin{tabular}{|l|l|l|l|}
\hline \multirow{2}{*}{$\begin{array}{l}\text { Unsur } \\
\text { Kimia }\end{array}$} & \multicolumn{3}{|c|}{ Hasil Pengujian } \\
\cline { 2 - 4 } & Sampel A & \multicolumn{1}{|c|}{ Sampel B } & Sampel C \\
\hline $\mathrm{C}$ & 0.41811 & 1.56890 & 1.37991 \\
\hline $\mathrm{Si}$ & 0.7725 & 0.21205 & 0.32604 \\
\hline $\mathrm{S}$ & 0.0018 & 0.0465 & 0 \\
\hline $\mathrm{P}$ & 0.0127 & 0.0022 & 0.0039 \\
\hline
\end{tabular}


${ }^{1}$ Amir , ${ }^{2}$ Murtalim, ${ }^{3}$ Muhammad chusnan Apriyanto, ${ }^{4}$ Muhamad Arif Rahman, ${ }^{5}$ Abel Alfarez Vol 5 No 1 ISSN : 2541-6995 E ISSN : 2580-5517

\begin{tabular}{|l|l|l|l|}
$\mathrm{Mn}$ & 0.75807 & 0.23312 & 0.51665 \\
\hline $\mathrm{Ni}$ & 43.81441 & 54.61879 & 46.95169 \\
\hline $\mathrm{Cr}$ & 3.48557 & 26.25288 & 38.10393 \\
\hline $\mathrm{Mo}$ & 0.16925 & 0.21160 & 0.1285 \\
\hline $\mathrm{V}$ & 0.02921 & 0.01792 & 0.01808 \\
\hline $\mathrm{Cu}$ & 0.17527 & 0.05907 & 0.07404 \\
\hline $\mathrm{W}$ & 0.15486 & 0.20650 & 0.18327 \\
\hline $\mathrm{Ti}$ & 0.00682 & 0.00472 & 0.00425 \\
\hline $\mathrm{Sn}$ & 0.00335 & 0.00290 & 0.00234 \\
\hline $\mathrm{Al}$ & 0.02152 & 0.01508 & 0.01329 \\
\hline $\mathrm{Pb}$ & 0.05128 & 0.04796 & 0.06426 \\
\hline $\mathrm{Nb}$ & 0.00060 & 0.00560 & 0.00643 \\
\hline $\mathrm{Zr}$ & 0.00474 & 0.00402 & 0.00218 \\
\hline $\mathrm{Zn}$ & 0.00898 & 0.00625 & 0.02604 \\
\hline $\mathrm{Fe}$ & 19.5413 & 17.0210 & 12.7589 \\
\hline
\end{tabular}

\section{Hasil Pengujian Metalografi}

Pengujian Metalografi dilakukan terhadap material rantai di daerah yang mengalami kerusakan yaitu pada daerah yang mengalami putus/patah dengan melakukan tiga sampel pengujian untuk mendapatkan struktur micro. Penelitian difokuskan pada daerah yang mengalami patahan dimana terdapat sambungan las, dengan pengujian ini dapat terlihat pada gambar dibawah ini
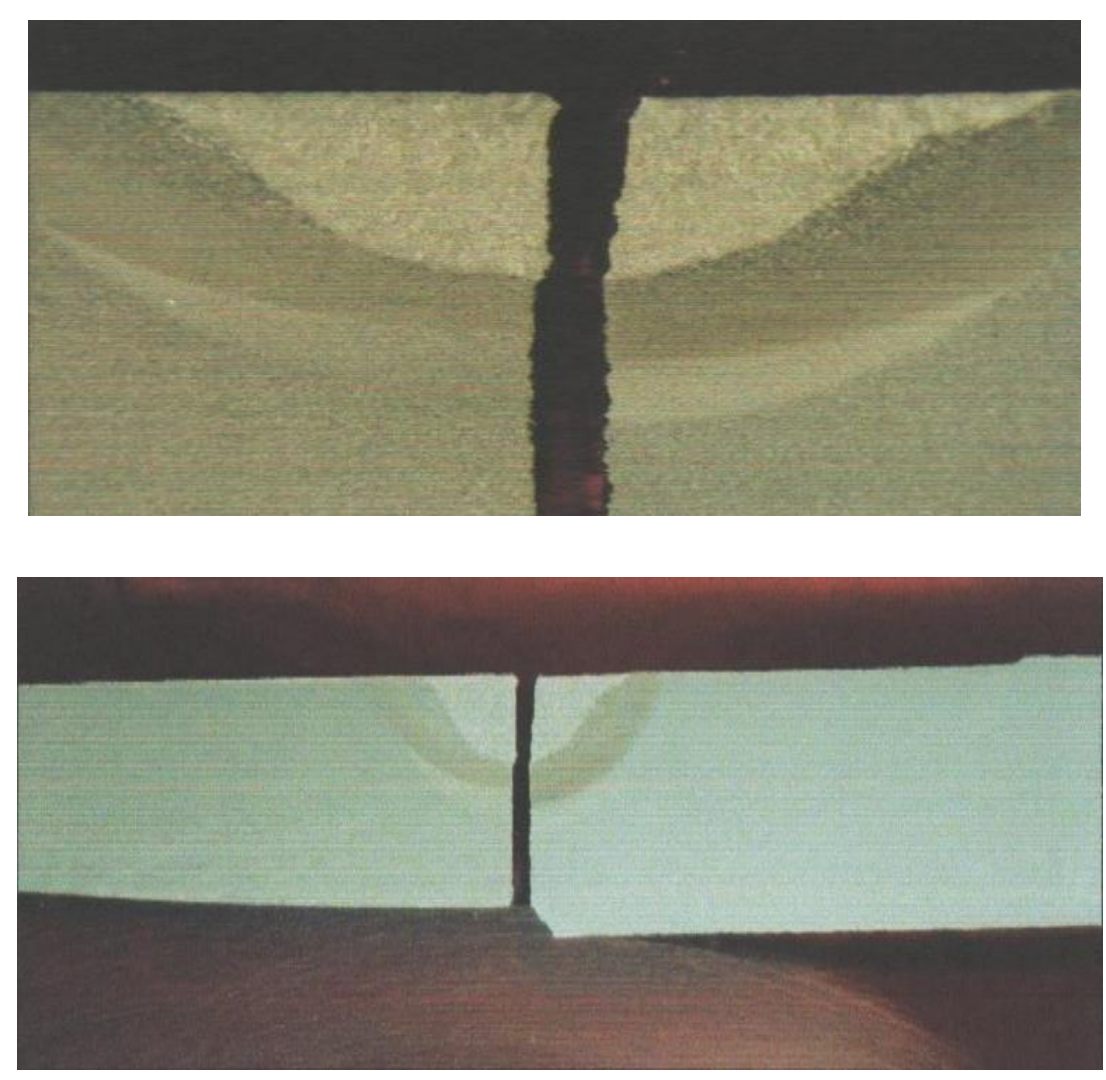

Gambar 1. Photo makro etsa pada sambungan las. Etsa : Nital 2\% 
${ }^{1}$ Amir , ${ }^{2}$ Murtalim, ${ }^{3}$ Muhammad chusnan Apriyanto, ${ }^{4}$ Muhamad Arif Rahman, ${ }^{5}$ Abel Alfarez Vol 5 No 1

ISSN : 2541-6995

E ISSN : 2580-5517
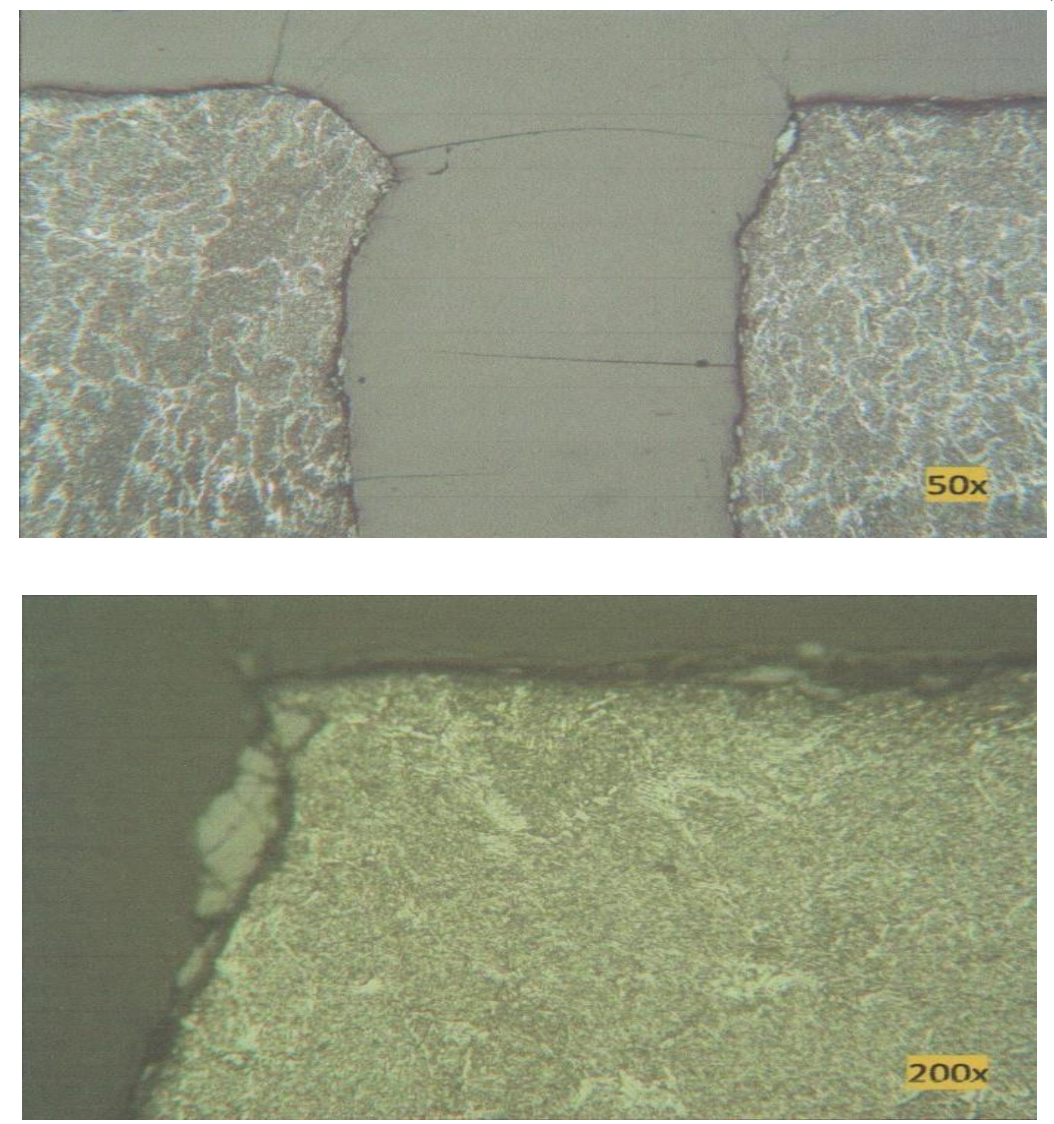

Gambar 2. Struktur micro daerah patahan berupa Bainit dengan pro-euteltoid ferit. Etsa: nital 2\%
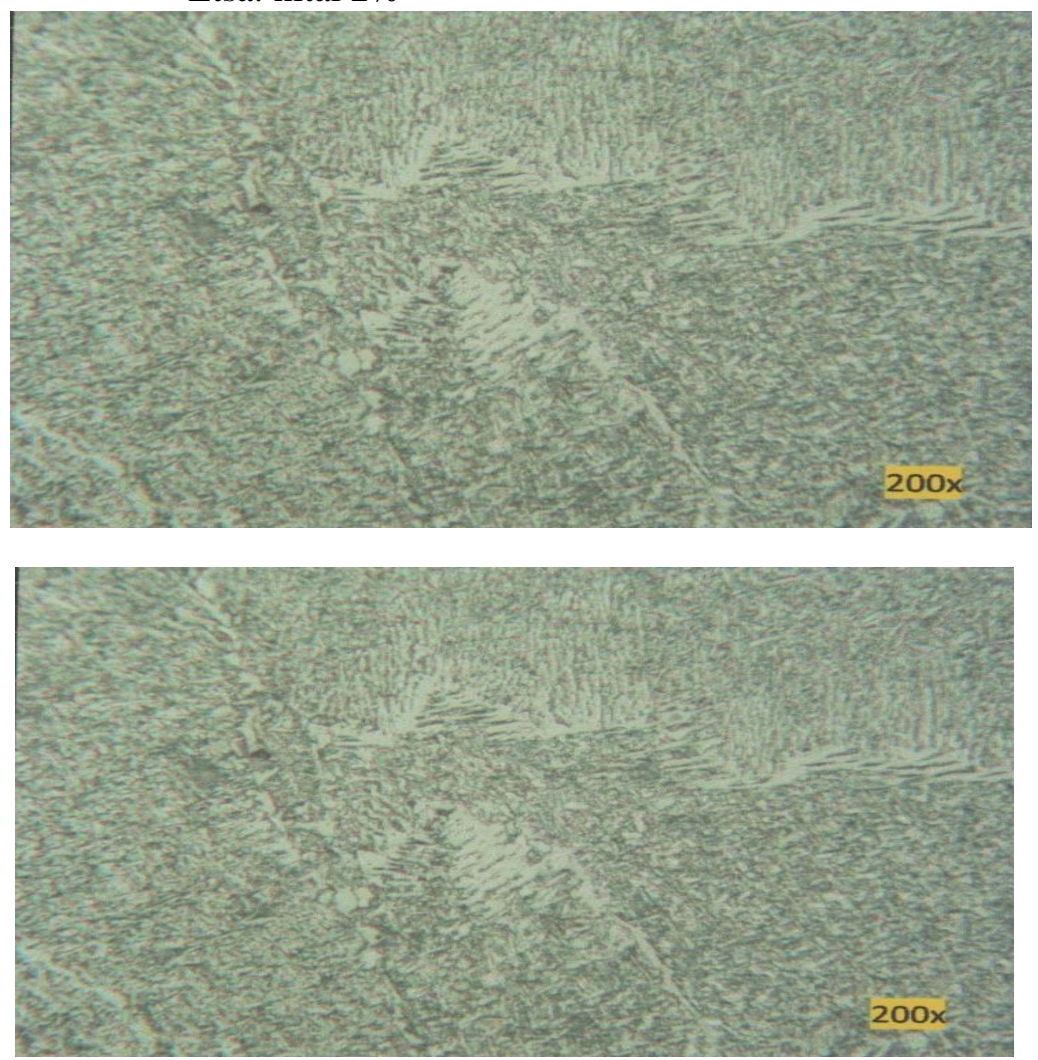

Gambar 3 . Struktur micro daerah materi lasberupa bainit dengan pro-eutektoid ferit. Etsa: Nital 2 
${ }^{1}$ Amir , ${ }^{2}$ Murtalim, ${ }^{3}$ Muhammad chusnan Apriyanto, ${ }^{4}$ Muhamad Arif Rahman, ${ }^{5}$ Abel Alfarez Vol 5 No 1

ISSN : 2541-6995

E ISSN : 2580-5517
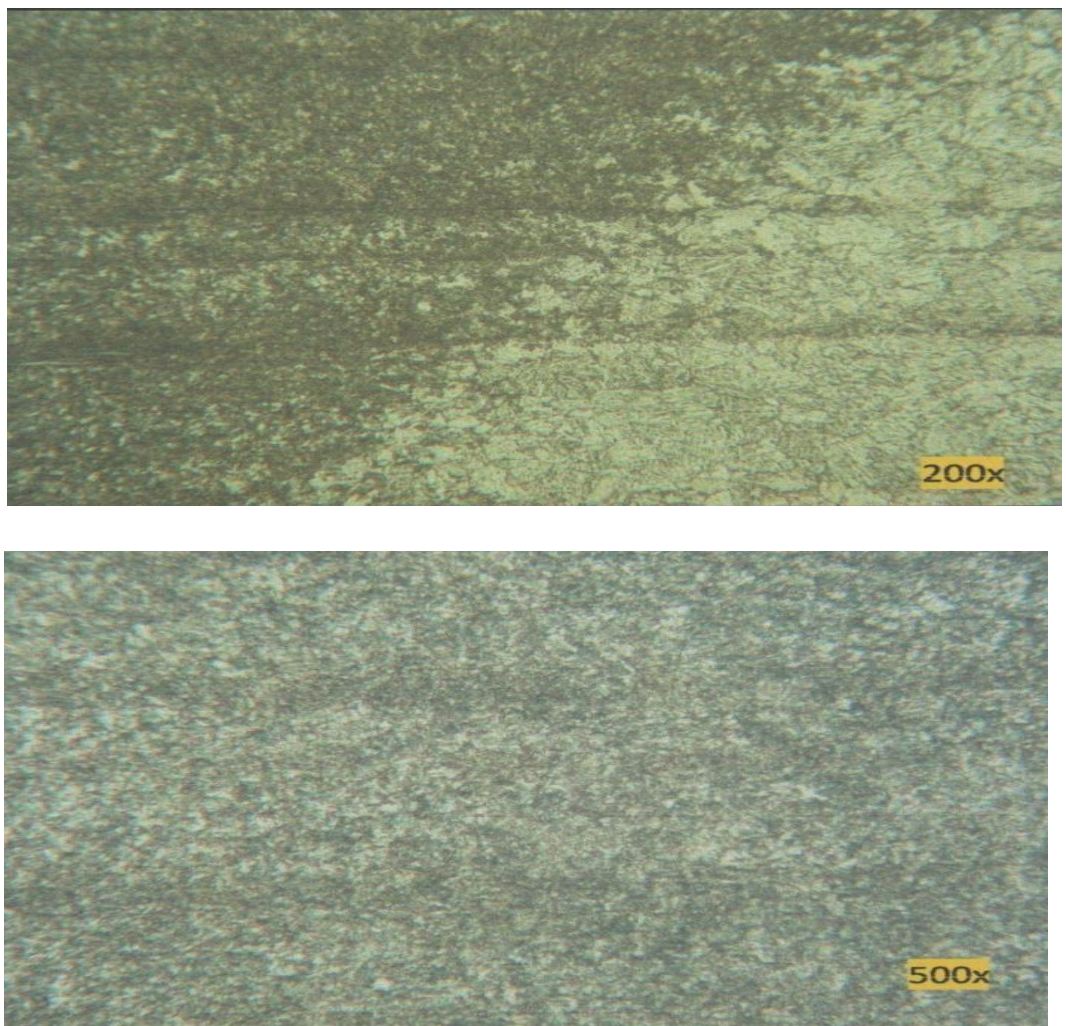

Gambar 4. Struktur micro batas daerah transisi pengaruh gaya beban ke HAZ. Struktur micro transisi HAZ berupa Martensit dan austenite sisa. Etsa : Nital 2\%
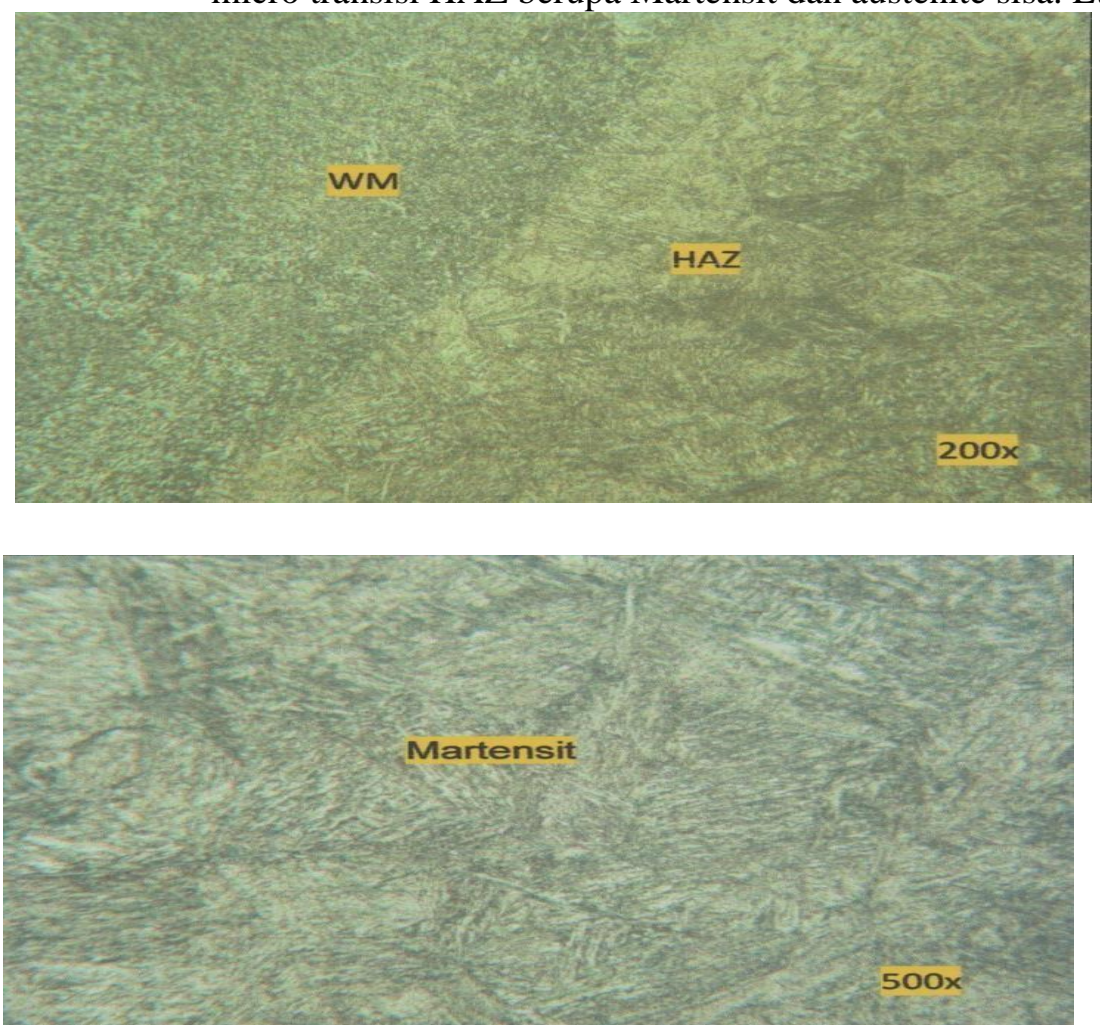

Gambar 5. Struktur micro batas daerah las dengan HAZ. Struktur micro HAZ berupa bainit Martensit Etsa : Nital 2\% 
${ }^{1}$ Amir , ${ }^{2}$ Murtalim, ${ }^{3}$ Muhammad chusnan Apriyanto, ${ }^{4}$ Muhamad Arif Rahman, ${ }^{5}$ Abel Alfarez Vol 5 No 1

ISSN : 2541-6995

E ISSN : 2580-5517
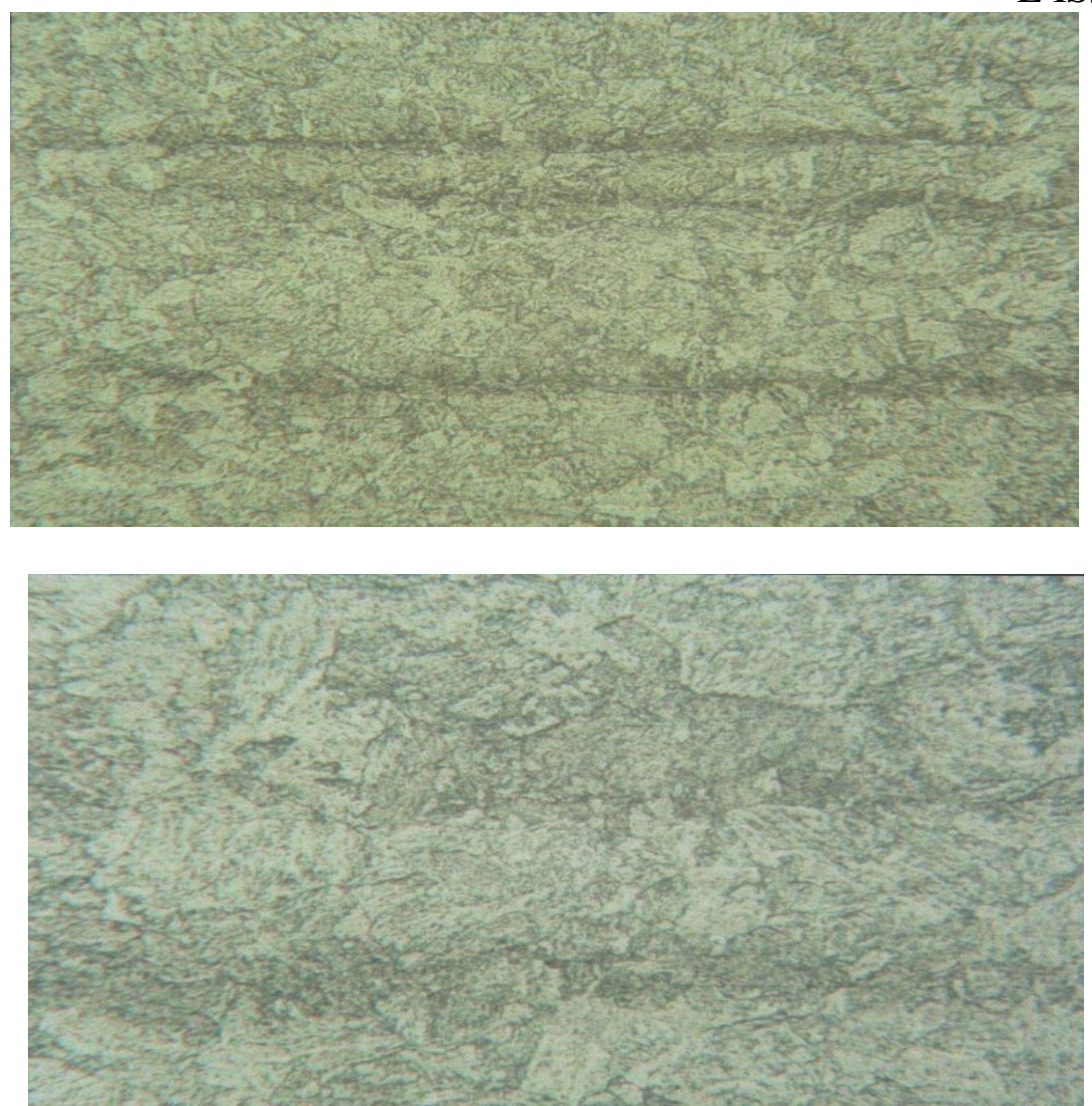

Gambar 6. Struktur micro dasar berupa bainit (austenite perlit) Etsa : Nital 2\%

\section{Hasil Pengujian kekerasan}

Pengujian kekerasan material pada masing-masing penampang di setiap sampel dilakuka dengan menggunakan metode Vickers dengan beban $187.5 \mathrm{kgf}$ dan dapat dilihat pada table 2

\begin{tabular}{|c|c|c|c|c|}
\hline \multirow{2}{*}{ No Uji } & \multicolumn{3}{|c|}{ Kekerasan Brinell ( HB : 30 ) } & \multirow[t]{2}{*}{ Keterangan } \\
\hline & Sampel A & Sampel B & Sampel C & \\
\hline 1 & 343,2 & 235,5 & 270,4 & \multirow{6}{*}{$\begin{array}{l}\text { Pogram Kekerasan Brinell ( HB : } \\
30 \text { ) } \\
\emptyset \text { Indentor } 2,5 \mathrm{~mm} \\
\text { Beban } 187,5 \mathrm{Kgf}\end{array}$} \\
\hline 2 & 338,8 & 265,5 & 284,8 & \\
\hline 3 & 334,4 & 266,2 & 295,6 & \\
\hline 4 & 334,4 & 258,5 & 311,2 & \\
\hline 5 & 320 & 272,5 & 320,0 & \\
\hline Rata - rata & 334,2 & 259,6 & 296,4 & \\
\hline
\end{tabular}

\section{Pembahasan}

Pembahasan tentang patahnya/putusnya rantai konveyor ini dimulai dari pengamatan secara visual, pengukuran dimensi rantai konveyor dan kemudian dilanjutkan dengan 
${ }^{1}$ Amir , ${ }^{2}$ Murtalim, ${ }^{3}$ Muhammad chusnan Apriyanto, ${ }^{4}$ Muhamad Arif Rahman, ${ }^{5}$ Abel Alfarez Vol 5 No 1 ISSN : 2541-6995

E ISSN : 2580-5517

beberapa pengujian yang dianggap sebagai penyebab terjadinya patah/putusnya rantai konveyor tersebut.

\section{Tinjauan Komposisi Kimia Material Rantai Konveyor}

Pada pengujian komposisi kimia materia rantai konveyor untuk material tersebut tergolong jenis baja panduan karbon sedang dengan jumlah presentasi karbon $4 \%$, yaitu sebesar 0,39\%untuk base metal, dan dan materialkadar karbon 0, 56\%, tingginya kadar karbon pada material tersebut disebabkan karena factor proses pengelasan. Material rantai tersebut mendekati material untuk alloy steel yang memiliki kemampuan kekuatan torsional dan kekuatan fatique yang baik sehingga pemilihan bahan yang sesuai untuk pemakaiannya sebagai rantai konveyor.

Dari hasil pengujian komposisi kimia ada tiga unsur yang melebihi normal yaitu nilai unsur C (karbo), Mn ( mangan), dan Mo (molybdenum). Tingginya nilai kadar karbon pada daerah sambungan las namun kadr komposisi kimia yang lainnya masih sesuai untuk material rantai SS304. Peningkatan nilai karbon ini memberikan nilai efek bertambahnya kekerasan pada bagian sambungan las tersebut dan dapat menyebabkan fatique.

\section{Tinjauan Kekerasan Material Rantai Konveyor}

Pengujian kekerasan dilakukan lokasi yang berdeda pada bagian ellbow yaitu di sampel A, sampel B dan sampel C. Nilai kekerasan rata-rata pada tiap sampel berdeda yaitu nilai kekerasan di sampel A 334.2 HV, sampel B 259,6 HV dan sampel C 296.4 HV.

Dari hasil pengujian kekerasan yang dilakukan pada tiga sampel diatas, maka nilai sampel B dan sampel C, pada base metal menunjukan nilai yang cukup seragam, dan tidak ada perubahan yang signifikan terhadap nilai kekerasan yang terjadi. Sedangkan dari pengujian kekerasan yang dilakukan pada sampel A material tersebut tidak terdapat perbedaan yang mencolok diantara hasilnya, namun nilai kekerasannya lebih tinggi jika dibandingkan dengan nilai kekerasan pada sampel B dan sampel C, bila dibandingkan dengan nilai standar kekerasan material SS 304 terjadi perbedaan yang tidak signifikan dengan kondisi material yang mengalami treatment annealing. Ketidakseragaman nilai yang terjadi pada hasil pengujian kekerasan tersebut dikarenakan telah terjadi penurunan nilai HAZ pada daerah lasan yang dibawah standar material yang diijinkan sehingga dapat menyebabkan terjadinya patah/putus pada daerah sambungan las tersebut.

\section{Tinjauan Metalografi Material Rantai Konveyor}

Pada hasil pengujian struktur micro yang dilakukan dengan tiga sample,sample pertama untuk struktur mikro pada daerah weld metal, sample kedua untuk daerah HAZ dan 
${ }^{1}$ Amir , ${ }^{2}$ Murtalim, ${ }^{3}$ Muhammad chusnan Apriyanto, ${ }^{4}$ Muhamad Arif Rahman, ${ }^{5}$ Abel Alfarez Vol 5 No 1 ISSN : 2541-6995

E ISSN : 2580-5517

sampel ketiga untuk daerah base metal. Daerah patahan/putus ditunjukan pada gambar 4.10 terlihat daerah HAZ dan base metal berupa Bainit dengan pro-euteltoid, gambar 4.11dan 4.12 menunjukan Struktur micro HAZ berupa bainit Martensit.

Dari hasil pengujian metalografi maka dapat disimpulkan bahwa pada strktur material SS 304 pada daerah HAZ ini memiliki konsentarsi yang tegangan dan kekerasan yang tinggi sehingga menjadi daerah yang rawan dan kritis terhadap fatique akibat tidak adanya PWHT (Post Welding Heat Treatment), tinginya nilai kekerasan pada daerah HAZ ini dapat mengakibatkan dearah tersebut semakin rentan terhadap putusnya material rantai konveyor tersebut.

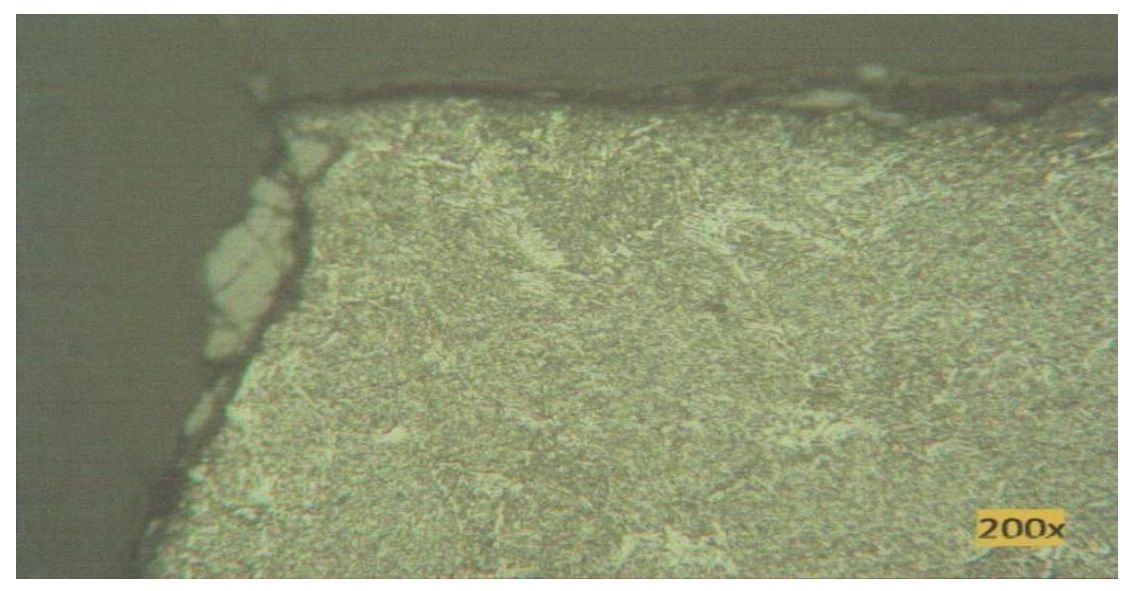

Gambar 8 daerah HAZ dan base metal berupa Bainit dengan pro-euteltoid

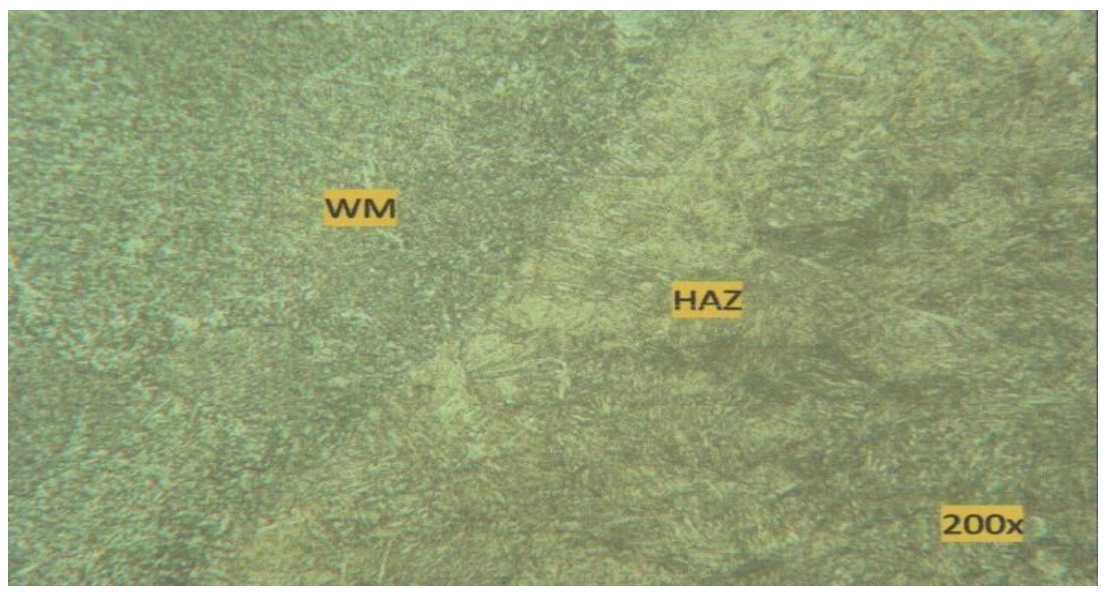

Gambar 9 Struktur micro HAZ berupa bainit Martensit. 
${ }^{1}$ Amir , ${ }^{2}$ Murtalim, ${ }^{3}$ Muhammad chusnan Apriyanto, ${ }^{4}$ Muhamad Arif Rahman, ${ }^{5}$ Abel Alfarez Vol 5 No 1 ISSN : 2541-6995 E ISSN : 2580-5517

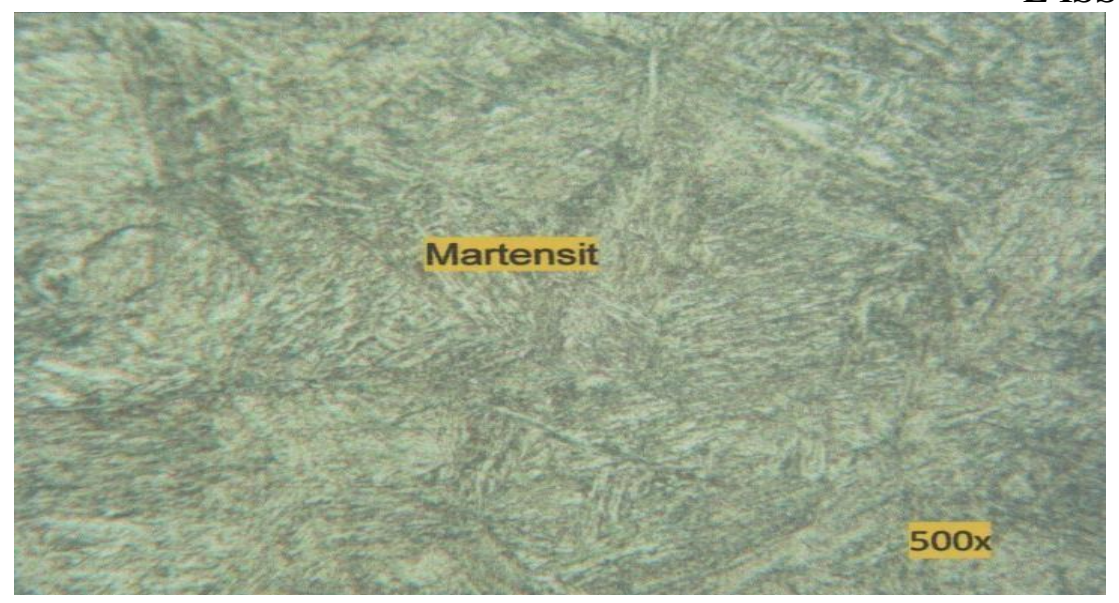

Gambar 10 Struktur micro HAZ berupa bainit Martensit.

Berdasarkan pengamatan secara visual dan Pengujian komposisi kimia Pengujian metalografi, pengujian kekerasan, dan analisa terhadap material rantai konveyor yang mengalami patah/putus, maka dapat disimpulkan sebagai berikut:

Penyebab terjadinya patah/putusnya rantai konveyor yaitu dikarenakan material rantai konveyor tersebut memiliki konsentarsi tegangan dan kekerasan yang tinggi sehingga menjadi daerah yang rawan dan kritis terhadap fatique akibat tidak adanya PWHT (Post Welding Heat Treatment), tinginya nilai kekerasan pada daerah HAZ ini dapat mengakibatkan dearah tersebut semakin rentan terhadap putusnya material rantai konveyor tersebut

\section{KESIMPULAN DAN IMPLIKASI}

\section{Kesimpulan}

Berdasarkan penelusan dari sampel material rantai konveyor yang mengalami kerusakan berupapatah/putus pada bagian sambungan las, maka dapat diambil kesimpulan yang menjelaskan sebab terjadinya patahan/putusnya rantai conveyer tersebut adalah sebagai berikut:

1. Penyebab dari putusnya rantaiconveyor tersebut lebih disebabkan olehkekuatan sambungan las yang bersifat brittle dikarenakan memiliki struktur micro martensit, sehingga dapat memudahkan rantai konveyor mudah putus disaat menerima bebab yang diatas beban ijinnya, sehingga patah/putusnya rantai conveyor ini lebih disebabkan oleh adanya beban fatique yang terjadi pada saat rantai conveyor khususnya pada bagian sambungan las, dikarenakan oleh desain rantai konveyor pada bagian las yangtidak dilakukan PWHT maka pada bagian sambungan tersebut terdapat tegangan sisa dan memiliki tingkat kekerasan material yang tinnggi. 
${ }^{1}$ Amir , ${ }^{2}$ Murtalim, ${ }^{3}$ Muhammad chusnan Apriyanto, ${ }^{4}$ Muhamad Arif Rahman, ${ }^{5}$ Abel Alfarez Vol 5 No 1

ISSN : 2541-6995

E ISSN : 2580-5517

2. Kondisi operasional yang memungkinkan terjadinya putus/patah pada bagian sambungan las rantai tersebut dapat mengakibatkan kerusakan ke komponen yang lain.

3. Besarnya beban yang bekerja diluar dari jangkaun yang di ijinkan.

\section{Saran}

Berdasarkan kasus yang terjadi pada material rantai yang mengalami kerusakan berupa putus/patah pada bagian rantai konveyor tersebut, maka beberapa langka di ambil guna mencegah terjadinya kejagdian serupa di masa yang akan datang maka saran dari peneliti yaitu desain sambungan las perlu di tinjau ulang dengan mempertimbangkan kekuatan rantai konveyor jikamenggunkan satu bahan yangutuh hal ini akan memberikan kekuatan yang cukup baikapabila menahan beban yang cukup, apabila dengan alasan tersebut tentu dsain sambungan las tetapdi pertahankan maka disarankan pada saatproses pengelasan dilakuka PWHT ( Post Welding Heat Treatment) yang akan memperbaiki struktur mikro material khususnya pada sambungan las sehingga dapat meningkatkan ductility dan menurunkan residual stress.

\section{DAFTAR PUSTAKA}

1. American Society of Material. Handbook Vol 09. Metallography and Microstructures, 2004.

2. Charlie. R. Brooks and Ashok Choudhury. Metallurgical Failure Analysis, McGrawHill. Inc, United Stated of America. 1993

3. DAS, AK. Metallurgy of Failure Analysis, New Delhi: Tata McGraw-Hill Publishing Company Limited.1996

4. Spivakovsky,A., CONVEYOR and RELATED EQUIPMENT, MIR PUBLISHER., MOSCOW, 1980

5. Strakosch, G.R., ELEVATOR and ESCALATOR, JOHN WILEY \& SONS, NEW YORK, 1978

6. Rudenko, MATERIAL HANDLINGS, GRAW-HILL, NEW YORK, 1978

7. E.A. Walters, CHAIN CONVEYORS and BUCKET ELEVATORS Proceedings of 4th Bulk Handling Seminar. University of Pittsburgh, December 1971

8. S. G.Pajer, H.Kuhnt and F.Kurth, STETIGFORDERER 1976 VEB Verlag, Berlin

9. G. Salzer, STETIGFORDERER 1964 Krauskopf Verlag, Mainz

10. Wilbur G. Hudson (1963), CONVEYOR and RELATED EQUIPMENT John Willey \& Sons, New York

11. T, Awaludin. Rantai Konveyor, 2004, Universitas Sumatra Utara 